Wilfrid Laurier University

Scholars Commons @ Laurier

\title{
Claiming the City: Co-operation and Making the Deal in Urban Comprehensive Land Claims Negotiations in Canada
}

Christopher Alcantara

Wilfrid Laurier University, calcantara@wlu.ca

Jen Nelles

University of Toronto

\section{Recommended Citation}

Alcantara, Christopher and Nelles, Jen, "Claiming the City: Co-operation and Making the Deal in Urban Comprehensive Land Claims Negotiations in Canada" (2009). Political Science Faculty Publications. 1. https://scholars.wlu.ca/poli_faculty/1 


\title{
Claiming the City: Co-operation and Making the Deal in Urban Comprehensive Land Claims Negotiations in Canada
}

\author{
Christopher Alcantara Wilfrid Laurier University \\ JEN Nelles University of Toronto
}

\section{Introduction}

Comprehensive land claims (CLC) agreements, otherwise known as modern treaties, have had a powerful effect on Aboriginal peoples in Canada. These agreements, which can only be negotiated by those Aboriginal groups that have never signed treaties, are supposed to empower Aboriginal peoples by transferring to them significant amounts of land, money, power, and authority. Frequently, such treaties also involve the creation of Aboriginal self-government, either as part of the land claims agreement itself or through a separate agreement and always require Aboriginal peoples to relinquish their undefined Aboriginal rights in exchange for a set of defined rights listed in the treaties. By gaining these resources, jurisdictions, and self-government rights, Aboriginal groups hope to have the tools to successfully protect their cultures, govern themselves more effectively, and foster greater economic wealth and independence.

Since the creation of the CLC negotiations process in 1973, only 22 Aboriginal groups have completed treaties while many others have not. A number of scholars and practitioners have speculated as to why some Aboriginal groups have been unable to complete treaties. Several commentators point to the fact that treaties are completed only when the

\footnotetext{
Acknowledgments: The authors would like to thank the two anonymous reviewers of this journal for providing helpful advice on an earlier version of this manuscript. Thanks to David Chandonnet for his help with the French abstract. Finally, we would like to thank the federal, territorial, municipal, and Kwanlin Dün officials who generously shared their time and knowledge with us.
}

Christopher Alcantara, Department of Political Science, Wilfrid Laurier University, Waterloo, ON N2L 3C5, calcantara@wlu.ca.

Jen Nelles, Innovation System Research Network, University of Toronto, Toronto, ON M5S 3G3, jen.nelles@utoronto.ca. 
claimed lands contain significant resource development opportunities for Canadian governments and businesses (Rynard, 2001; Feit, 1980; Diamond, 1985). Others argue that negotiations tend to take a long time because Aboriginal and government actors bring different understandings of the treaty process to the negotiating table (Tully, 2001; Abele and Prince, 2003). Former Yukon Premier Tony Penikett (2006) and scholars Ravi De Costa (2003), Colin Samson (1999), and Andrew Woolford (2005) place the blame on uninterested governments, unmotivated negotiators, and the inherent power imbalances found within the negotiating process. Finally, Christopher Alcantara (2007) suggests that variation in treaty negotiation outcomes can be best understood by examining, on the one hand, the institutional structures governing treaty negotiations and, on the other, the goals and strategies employed by participating Aboriginal actors.

Although all of these contributions have furthered our knowledge about modern treaty negotiation outcomes in Canada, none looks at the complications that arise when lands within a major municipality are involved. This omission in the literature is surprising since a significant number of treaty negotiations in Canada involve or have involved municipal lands. These types of negotiations need further study since they are crucial sites of contestation between competing Aboriginal and nonAboriginal claims.

The purpose of this paper is to examine the complications that arise when municipal lands are at the centre of modern treaty negotiations. More specifically, we suggest that co-operation between First Nations and municipal governments is unlikely to occur unless a number of theoretical factors are present. To develop this argument, we conducted interviews and gathered primary and secondary sources to study the Kwanlin Dün First Nation treaty negotiations in the Yukon Territory. Although there were no direct negotiations between the Kwanlin Dün First Nation and the city of Whitehorse, their ability to co-operate indirectly with each other was crucial for the completion of the treaty. ${ }^{1}$ We focus on this particular case because it was the first modern treaty involving land located in a major municipality. As well, many observers at the time believed that Kwanlin Dün's treaty would never be completed because its claim involved municipal lands. Yet Kwanlin Dün was able to complete a treaty in 2005 . As such, this paper will be relevant to other sets of treaty negotiations involving land located within major municipalities.

The structure of this paper is as follows. It begins by providing some background information on modern land claims in Canada before outlining a theoretical framework through which bilateral relations between First Nations and municipal governments can be analyzed. This perspective is adapted from Nelles' (2009) theory of intermunicipal co-operation which 
Abstract. Since their introduction in 1973, comprehensive land claims (CLC) agreements have become important mechanisms for Aboriginal peoples to achieve their political, social, cultural, and economic goals. Although the literature on CLC negotiations is a rich and varied one, it has tended to ignore the role that municipal governments have on influencing negotiation outcomes. This lacuna is surprising since a number of treaty negotiations in the Yukon Territory and BC involve lands located in major municipalities. This paper develops a theoretical framework for understanding the influence that municipal governments can have on treaty negotiation outcomes. Using a case study of the Kwanlin Dün First Nation treaty negotiations in the Yukon Territory, we find that institutional and milieu factors are important. However, leadership was the most important and decisive factor.

Résumé. Depuis leur apparition en 1973, les ententes portant sur les revendications territoriales globales sont devenues des mécanismes importants pour les peuples autochtones dans l'atteinte de leurs objectifs politiques, sociaux, culturels et économiques. Bien que la documentation sur ces ententes soit volumineuse et variée, elle tend à ignorer le rôle influent que jouent les administrations municipales lors de telles négociations. Cette lacune est surprenante, dans la mesure où plusieurs de ces traitésconcernaient des territoires situés dans des zones urbaines d'importance de la Colombie-Britannique et du Yukon. Cet article vise à développer un cadre théorique pour mieux comprendre l'influence des administrations municipales dans le dénouement de négociations territoriales. En utilisant l'étude de cas des négociations de la Première nation de Kwanlin Dün au Yukon, nous constatons l'importance de la structure institutionnelle et communautaire. Cependant, le leadership demeure le facteur le plus crucial lors d'un tel processus.

argues that although institutional and milieu variables are important to structuring relations and incentives, often the most powerful explanation for co-operative outcomes is related to regional stocks of civic capital and factors such as leadership and networks. The case of the Kwanlin Dun treaty negotiations is examined using this theoretical lens. Finally, the paper concludes that, while institutional and milieu factors are key to understanding the successful resolution of this land claims agreement, leadership was the most decisive factor.

\section{Background Considerations}

The Canadian federal government has established two negotiation processes for managing its treaty relationship with Aboriginal peoples: the specific claims process and the comprehensive land claims (CLC) process. The specific claims process is designed to address alleged wrongs or mistakes committed by the federal government in its interpretation and implementation of Aboriginal treaties. It can also be used by nontreaty Aboriginal groups to address the federal government's mismanagement of Indian assets.

The second process, and the one that is the focus of this article, is the CLC process created in 1973. Up to 1921, the federal government had been negotiating land surrender treaties with Aboriginal peoples in western and northern Canada. In 1921, the federal government ended 
its policy of negotiating new treaties. In its place, it employed a variety of assimilation mechanisms designed to bring Aboriginal peoples into mainstream society. In response, Aboriginal peoples began to organize themselves politically in the 1960 s to protect their lands and ways of life (Scholtz, 2006). The key turning point was in 1973, when the Supreme Court of Canada ruled that Aboriginal title did in fact exist. Shortly thereafter, Prime Minister Trudeau announced that his government would begin treaty negotiations to facilitate the exchange of undefined Aboriginal rights for a set of specific treaty rights (Alcantara 2008).

Since 1973, 22 groups have completed modern treaties while many others, most of which are located in British Columbia, have not. Of those Aboriginal groups still negotiating under the comprehensive land claims process, approximately 35 involve Aboriginal-claimed lands that fall within municipal boundaries. Unfortunately, we are unable to determine with precision how many negotiations involve municipal land transfers because most negotiations have yet to reach the land selection stage. For those negotiations that have progressed to the stage where municipal land transfers may be under consideration, government and Aboriginal officials have refused to comment on whether they are considering municipal land transfers. Nonetheless, it is clear that a significant number of ongoing negotiations involve Aboriginal-claimed lands within municipal boundaries and therefore the case of the Kwanlin Dün will be of relevance to those negotiations. According to one anonymous government official, First Nations tend to choose sites that fall within the boundaries of Canada's major cities. Historically, many Aboriginal groups spent considerable time at locations along and at the intersection of major rivers, streams, and waterbodies. These areas, which were valuable gathering places prior to contact, remain so today. As a result, municipalities are extremely interested in how treaties will affect their lands and jurisdictions. Therefore, securing municipal co-operation either directly (through negotiating municipal land transfers) or indirectly (through regular consultations) is a very important goal for federal, provincial, territorial, and Aboriginal governments, if just to allay municipal political opposition to future settlements.

The KDFN negotiations are an especially appropriate and crucial case because commentators and officials at the time believed that it would be one of the most difficult among the Yukon negotiations to complete, since its claim involved municipal lands in a territorial capital. As well, some observers pointed to a particularly confrontational negotiator and to significant internal and leadership divisions as other crucial obstacles to treaty completion. Therefore, in many ways the KDFN treaty is a rigorous and ideal case for testing the applicability of interlocal co-operation theories to land claims agreements involving municipal lands. 


\section{Theoretical Framework}

According to Theresa Dust (1997) and city of Whitehorse officials, municipal governments have serious concerns about the impact of modern treaties on their citizens, lands, and jurisdiction. Specifically, municipal governments worry about the compatibility of municipal and Aboriginal laws with respect to land use, zoning, economic development, garbage collection, snow removal, parking meters, utilities, police services, and bylaw enforcement. They are also concerned about tax revenue losses resulting from the conversion of municipal lands into treaty settlement lands. Finally, municipal government actors face uncertainty with respect to the actual parcels of land that are to be transferred to the Aboriginal government. City of Whitehorse officials all mentioned that there was significant reluctance and apprehension regarding the possibility of an Aboriginal treaty affecting their authority within the city's boundaries.

Municipal reluctance and apprehension are also exacerbated by the fact that municipal governments do not have a seat at the negotiating table. Rather, CLC negotiations occur between the federal, provincial or territorial, and Aboriginal governments. The only way in which city officials can directly participate in negotiations is if the provincial or territorial government is willing to represent their concerns at the negotiating table. In essence, in most CLC negotiations municipal governments are reluctant, passive participants who have little incentive to co-operate.

Although municipal governments are not involved directly in the negotiations, they are involved indirectly through consultations with the provincial or territorial governments. These consultative processes are designed to seek municipal input and to gain municipal support for the completion of treaties. According to Dermot Flynn (2006), chief negotiator for the Yukon territorial government, the consultative processes used in the Yukon were used to gather input and to show municipal officials that Yukon First Nations were governments and not corporations who were going to flip the land for profit and private gain. Rather, the land was going to be held in collective ownership for the benefit of the First Nation governments and their citizens. Moreover, the consultative exercises were designed to show that First Nation governments had similar goals to municipal ones, especially with regard to economic development and the quality of life of their citizens.

The following section establishes a theoretical lens to examine bilateral relationships between First Nations and municipal governments. This framework is necessarily broad as it is intended to describe relations between these two types of government in general and is not specifically geared to CLC negotiations in which there are several intermediary actors (that is, federal, provincial, territorial and Aboriginal governments). However, in cases where the resolution of a CLC involves urban land trans- 
fer, a secondary transaction is often required, which will typically involve the sale of lands as well as an agreement regarding the conditions of transfer to which municipal governments must assent. Therefore, while this type of co-operation is not typically a factor in CLC negotiations outside of urban areas, the framework can be applied to cases where secondary negotiations require agreement between municipal governments and First Nations. Even if these negotiations are not direct and are conducted through an intermediary (such as the provincial or territorial government) the framework still holds. It is still a case where co-operation, whether tacitly or explicitly negotiated, is required between these two types of actors.

First Nations and municipal governments in Canada are comparable and can therefore be discussed in similar terms. In principle, both forms of government administer a territorially specified jurisdiction, provide services to their citizens, and participate in the implementation of policies developed at senior levels of government. Both are governed by a democratically elected council and leader. Tennant (2000) contends that while First Nations governments face a distinct set of challenges relative to non-Aboriginal communities, a large proportion of the daily concerns that occupy municipal politicians are also shared by First Nations leaders. Yet it is important to note that many First Nations reject the characterization of their governments as municipal, despite the similarities.

The most crucial differences in these two varieties of local government lie in their decision-making processes, and more importantly, in constitutional status. McAllister (2004) notes that while practical administrative concerns of governing a locality may be comparable to those of small municipalities, the process of decision making may vary depending on the traditions of the band. More emphasis may be placed on community participation in decision making and chiefs may have little autonomy in the face of broad opposition than other political leaders. There may also be more reliance on consensus-based decision making (McAllister, 2004: 24). Where this type of decision making prevails, comparisons can still be made with municipal governments, provided that these different dynamics and incentive structures are recognized. For instance, in such cases the motivations for leadership decisions cannot be read exclusively from the agendas and incentives faced by formal leaders.

As is the case with municipal governments, institutional and constitutional status varies from province to province. Broadly speaking, constitutional differences emerge to the extent that First Nations communities have a relationship directly with the federal government - as well as with the provinces - while municipalities in Canada have delegated authority through provincial or territorial governments. ${ }^{2}$ The 1988 amendment of the Indian Act extended taxation powers akin to those held by municipal- 
ities to band councils, thereby providing Aboriginal governments with comparable tools for economic development and self-government.

Therefore, while we would certainly not contend that municipal governments and First Nations bands share the same set of considerations or incentive structures, they are certainly similar in a number of respects. For the purposes of examining municipal-First Nation bilateral relations, particularly in urban areas, a framework delimiting intermunicipal relations can be legitimately adapted. ${ }^{3}$

The theoretical literature on intermunicipal co-operation is relatively well developed (see especially Feiock, 2007; Feiock, 2004; Steinacker, 2004 Post, 2004 Oakerson, 2004). However, it suffers the general shortcoming that it tends to be very US-centric and reliant on a narrow rational-choice perspective. The application of this approach to intermunicipal co-operation has some utility in outlining the incentive structures faced by the various actors in the partnership negotiations across many areas of co-operation. Rational-choice perspectives, however, tend to rely heavily on the characteristics of the issue at the heart of co-operation to explain outcomes (Feiock, 2007; Steinacker, 2004; Post, 2004). This has the twin result of privileging specific issues, such as visible costs, over the institutional factors that may affect political decisions, making conclusions very issue and context specific. While rational-choice approaches are helpful in describing the incentive structures that shape the preferences of individual actors over time, in the application to intermunicipal co-operation literature, these are less effective in identifying the effect of more stable political structures on co-operative outcomes. Ostrom (2005) argues that second-generation rational-choice theories are beginning to address the institutional dimensions of co-operation. However, many of these approaches are still quite narrowly focused on the internal dimensions of partnership agreements or single-variable cases (Steinacker, 2004; Post, 2004). Few of these accounts of intermunicipal co-operation incorporate a broad spectrum of variables and, as such, there are no comprehensive theories of intermunicipal co-operation. Nor are those that attempt to address multiple variables (Feiock, 2007) structured to effectively address issues, such as the effect of leadership or civic networks, in structuring collective action. Consequently, a broader and more holistic framework has the potential to more effectively illuminate the dynamics at play in the negotiation of inter-local co-operative agreements.

Nelles (2009) advances just such an alternative approach to explain the emergence and intensity of intermunicipal co-operation. It combines aspects of rational choice with historical institutionalism to develop a framework of factors that may impact the decisions of local actors to engage, or not, in interlocal partnerships. This perspective argues that while these factors certainly have an effect on co-operation, their effects may be mitigated in regions where civic capital is more developed. Civic 
capital, derived in large part from a critique of social capital literature, is defined as interpersonal networks within a community based on a shared identity, expectations or goals and tied to a specific region of locality (Nelles and Wolfe, 2008). The concept emphasizes the importance of leaders - civic entrepreneurs - in intensifying and formalizing collaborative networks within and between communities. As such, the central focus of a civic capital approach is on the networks and leaders that make up the community and how they can be adapted to shifting policy opportunities. So, while institutional and contextual factors do indeed play an important role in shaping decision-making environments, the emergence of co-operation can often be explained more effectively with a view to the role of civic capital.

In the context of intermunicipal relations this approach combines geographical, institutional and milieu variables with an analysis of regional civic capital to explain the emergence and intensity of co-operation on regional economic development. A slightly modified version of this basic framework can be applied to co-operation between municipal and First Nations governments. Because these relationships tend to be bilateral, geographical factors - which deal with issues of group size - can be discarded. However, a number of institutional variables are still applicable. These variables describe the extent to which agendas and abilities align in any given context to produce a co-operative result.

Differences between the powers of mayor and chief may affect the facility with which agreements are reached. When a mayor or chief is hamstrung by indecisive councils, this may impact the shape and speed of co-operation. From this perspective, political leaders that have more autonomy may make decision making much easier to achieve. The degree of local autonomy may also impact co-operation. This factor can be conceptualized both in terms of jurisdictional and fiscal autonomy. When a municipal government has very few autonomous areas of jurisdiction, its political leadership may be wary of ceding authority when land claims involved a transfer of both territory and authority. Therefore, the degree to which this transfer affects municipal service delivery, for example, will have an effect on the form and outcome of intergovernmental co-operation. From a fiscal point of view the same principle holds. When municipalities have a wide variety of funding tools they may be more willing to cede taxing authority over a part of their tax base to First Nations groups. ${ }^{4}$

Power asymmetry is also an important factor to consider in co-operative relationships. The degree to which partners vary in their power will determine whether the relationship is coercive and also affect the motivations of the actors. Asymmetries in municipal-First Nations relations can stem from a variety of sources. In this case, the degree of bureaucratic organization or access to resources can impinge on infor- 
mation availability and bargaining chips in negotiations. Issues, such as public opinion, may also come into play under this variable. When the public is highly polarized or supportive of one actor over the other, this lends weight to the legitimacy of claims and increases (or decreases) the political costs of non-compliance. Interestingly, perceptions of power asymmetries can often impact the character of co-operation more than actual power distributions.

The final institutional variable is external government involvement, and the potential for the threat of upper-level government involvement. In the case of Kwanlin Dün treaty negotiations, government involvement is most likely to emerge from one or both upper levels of government. To the degree that municipal governments are the wards of the provincial and territorial governments, these actors have the ability to intervene. This intervention, or the threat of intervention, also shapes decisions. For instance, in the case of land claims, it is within the jurisdiction of the provincial government to expropriate municipal land for transfer to First Nations groups. Under such circumstances municipal governments may be more amenable to reaching a negotiated settlement.

Milieu variables are those non-institutional factors that may shape decisions to co-operate or not. These can be disaggregated into internal and external threats or opportunities. The presence of internal threats may increase the incentives for collaboration. For example, if the city faces high unemployment or high levels of social problems there may be an incentive to resist co-operation. However, the opposite may also hold true as the presence of shared problems may prompt collaborative solutions. Internal opportunities can be as potent as threats. When both parties stand to gain from a partnership or agreement co-operation is typically easier to negotiate. External threats can be as local as specific environmental problems or as global as the vagaries of the market. Whatever external factors may shape co-operative decisions should be taken into account in the analysis of collaborative behaviour. The effect, positive or negative, on the emergence of co-operation is entirely dependent on the nature of the threat or opportunity and the positions of the actors involved. It is conceivable that the same threat, for instance, would have different effects on the bargaining positions of each actor.

Finally, while each of these factors can play an important role in affecting municipal-First Nations relations, local civic capital can overcome barriers to co-operation or complement existing co-operative relationships. In intermunicipal relationships the concept of civic capital relies on gauging associational activity within a region, networks between associations, the presence and evolution of key civic leaders, and an assessment of the history of civic interaction. In the context of municipal-First Nations relationships the most important factors are leadership and the state of bridging networks. Social capital literature often ignores the 
impact of visionary leadership in the establishment of collaborative relationships (Brass and Krackhardt, 1999; Lowndes and Wilson, 2001). However, charismatic and forward-thinking leaders can often effectively bridge different networks (for instance, between municipal and First Nations leaders or bureaucracies) to forge co-operative links. Alternatively, or concurrently, co-operation can be built from below in the form of informal networks between communities based on self-interest. In other words, these networks need not necessarily be oriented towards a formal bridging of forums but can be based on a number of motivations (commercial, personal, social, and so forth) and either formalized, as part of an organization, or informal. Where there are visionary and charismatic leaders and robust networks, co-operation is more likely to emerge. However, these two factors are quite different to predict and measure. A detailed qualitative analysis is required to establish which actors and networks are relevant in co-operative negotiations. One critical point is that leadership is not always positive-it can be used negatively to oppose partnerships and collaborative solutions. That is why the presence of both leadership and complementary networks are important factors to determining where co-operation will emerge.

Taken together the variables outlined above constitute a range of factors that may influence the emergence of inter-local co-operation. It provides a framework with which to analyze empirical cases. However, one of the central hypotheses of Nelles' approach is that institutional and milieu variables may have different effects in different cases. Therefore, it is not expected that the same variables will be relevant across a variety of issues or cases. This model contends that, regardless of institutional or milieu effects, regions characterized by higher levels of civic capital will exhibit greater degrees of co-operative intensity and will be more likely to reach co-operative agreements.

\section{Kwanlin Dün Comprehensive Land Claims Negotiations: A Case of First Nation-Municipal Government Co-operation}

The Kwanlin Dün case illustrates the extent to which institutional and milieu variables can structure incentives for co-operation in land claims negotiations. Indeed, the "deal breaker" in this particular case was the transfer of waterfront lands from the City of Whitehorse to the Kwanlin Dün First Nation. The following section presents a history of the Kwanlin Dün treaty negotiations and outlines the key issues at stake. The negotiations are then analyzed using the theoretical framework elaborated above. While many institutional and milieu factors play a role in structuring the terms of these negotiations, leadership, armed with civic capital, proved decisive in securing an agreement. 
In contrast to other regions in Canada, Aboriginal peoples in the Yukon Territory had never signed treaties with the Crown nor did they ever receive reserve lands. After the Calder decision in 1973, the Yukon First Nations, of which there are fourteen, were one of the first Aboriginal groups in Canada to begin comprehensive land claims negotiations with the federal government. The Yukon First Nations were represented at the negotiating table by the Yukon Native Brotherhood (representing status Indians in the Yukon) and the Yukon Association of Non-Status Indians (DIAND, 2002; McClellan, 1987: 99-104). In late 1973, the federal government initiated negotiations by making "a unilateral, public offer of settlement" to the two organizations (Frideres, 1986: 289). Both groups quickly rejected the offer, forcing the federal government to change its offer into a working one open for negotiations. Formal negotiations began in early 1974 between the Yukon Native Brotherhood (YNB), the Yukon Association of Non-Status Indians (YANSI), and the federal government. At this point, the Yukon territorial government (YTG) did not have its own seat at the negotiating table. Rather, negotiations were bilateral and YTG officials sat as part of the federal negotiating team.

In 1979, the federal government invited YTG to join the negotiating table as a separate and equal negotiating party. One year later, the Yukon Native Brotherhood and the Yukon Association of Non-Status Indians decided to merge into the Council of Yukon Indians (CYI) to represent all Yukon Aboriginal peoples at the negotiating table (McClellan, 1987: 103). With the territorial government at the table and the Yukon Indian organizations amalgamated into one umbrella organization, comprehensive land claims negotiations moved forward relatively quickly.

In early 1984, the negotiators completed an agreement in principle (AIP). However, at its general assembly in Tagish, the CYI failed to ratify the AIP. In June 1987, the federal government, the YTG, and the CYI resumed land claims negotiations to negotiate a deal that would be acceptable to the membership of the CYI. The negotiators made swift progress and in 1989, the three parties signed a new AIP. Confident that the CYI would ratify it this time, the negotiators turned to drafting an umbrella final agreement. Again, negotiations proceeded quickly and in early 1993, the CYI, the federal government, and the YTG signed the umbrella final agreement, which transformed the AIP into a final treaty. In March 1993, the CYI at its usual quarterly board meeting ratified the umbrella final agreement despite the vigorous opposition of the Kaska nations. In 1994, Parliament passed settlement legislation officially bringing the umbrella final agreement into effect

The umbrella final agreement (UFA) is essential for understanding the Kwanlin Dün claim because the UFA is the framework that each Yukon 
First Nation must use to negotiate its individual final agreement. The UFA specifies the amount of land quantum and financial compensation that each Yukon First Nation will receive upon completing its individual final agreement. It also sets out the range of powers that each Yukon First Nation can negotiate. In essence, the UFA requires that all Yukon First Nations adopt its text as the basis for their own final agreements. Each First Nation can, however, negotiate "specific provisions" that clarify or slightly modify the original text according to the unique circumstances of the First Nation.

During the final stages of the UFA negotiations in the early 1990s, some federal, territorial, and Yukon First Nations officials were becoming impatient with the land claims process. Therefore, the parties agreed to allow the CYI to identify four Yukon First Nations to begin negotiating individual agreements concurrently with the UFA negotiations (Joe, 2006; Koepke, 2006; McArthur, 2006; Mitander, 2006). The four that were chosen were Champagne/Aishihik, Nacho Nyak Dün, Teslin Tlingit, and Vuntut Gwitchin. These first four Yukon First Nations completed final agreements in 1995. After these treaties were completed, the federal and territorial governments began negotiating with all of the remaining Yukon First Nations at separate tables.

\section{Kwanlin Dün First Nation Negotiations}

Kwanlin Dün negotiations commenced in late 1995, but very little progress was made until 1999. During these four years, negotiations were hampered or delayed by a number of factors. The most relevant obstacle for this study was the election of Joe Jack as chief of Kwanlin Dün First Nation in 1996. Upon taking office, he fired the entire staff of the land claims department, immediately ending land claims negotiations with the federal and territorial governments. Moreover, Chief Jack's action sparked a series of intense and highly publicized confrontations between his supporters and the supporters of the fired land claims staff, paralyzing the First Nation until the election of Rick O'Brien as chief in March 1999 (McNeely, 1998; Northern Native Broadcasting Yukon, 1998; ${ }^{5}$ Northern Native Broadcasting Yukon, 1996; Parker, 1999).

\section{Towards an Agreement: 1999 to 2002}

The election of Rick O'Brien was an important turning point because he was able to quell the political infighting that had plagued Kwanlin Dün since the mid-1990s. Moreover, O'Brien resurrected the land claims department and appointed a new department head, Tom Beaudoin, to restart land claims negotiations with the federal and territorial governments. In the eyes of federal and territorial officials, Beaudoin was a wel- 
come relief from the previous team. He immediately put together a new negotiating team to restart negotiations. Members of his team included lawyer Keith Brown, consultant Lindsay Staples, and Kwanlin Dün citizen and lawyer, Mike Smith, who would later become chief of Kwanlin Dün in 2003.

By 1999, three Yukon First Nations (Little Salmon/Carmacks First Nation, Selkirk First Nation, and Tr'ondëk Hwëch'in First Nation) in addition to the original four had completed individual final agreements. By the time Beaudoin's team was ready to restart negotiations in 1999, government negotiators felt they had completed enough of the other claims to begin focusing on the Kwanlin Dün. Rather than building on the work that the previous Kwanlin Dün negotiating team had accomplished during the mid-1990s, Beaudoin's team restarted negotiations from scratch. To speed up the process, his team identified a number of crucial issues that the three negotiating parties had to resolve before a treaty could be completed: the inclusion of waterfront lands in Whitehorse as settlement lands, clarification of the First Nation's self-government powers in the city (that is, land use planning), property taxation exemptions (because all land transferred under a treaty would immediately become taxable and would probably bankrupt Kwanlin Dün), and the development of more robust economic measures (because Kwanlin Dün lands had limited fish, wildlife, and resource opportunities to generate economic development) (Beaudoin, 2006; Brown, 2006; Flynn, 2006; Koepke, 2006; King, 2006).

Although negotiators made decent progress during the first year of negotiations with Beaudoin's team, two events helped negotiations move forward. The first was the appointment of Robert Nault (August 1999 to December 2003) as Minister of Indian and Northern Affairs Canada. In April 2000, Nault announced that the federal mandate to negotiate with the remaining Yukon First Nations would end on March 31, 2002, unless each of the tables could come to a memorandum of understanding to continue negotiations past the deadline (Tobin, 2000). Kwanlin Dün officials embraced the deadline as an opportunity to create pressure on themselves and on their government counterparts to complete a treaty.

The second event was the election of a progressive Whitehorse municipal council, led by Ernie Bourassa, mayor from 2000 to 2006. Throughout the course of Kwanlin Dün's negotiations, the city of Whitehorse had virtually no role in the negotiations. Although the city was allowed to send the occasional representative to observe negotiation sessions, it did not formally participate in negotiations. Rather, it was forced to rely on the territorial government to represent its interests (Armour, 2006; Bourassa, 2006; Flynn, 2006; McCullough, 2006; Stockdale, 2006). The city, however, still had an important influence on negotiations. Historically, Kwanlin Dün members had spent significant amounts of time living on the banks of the Yukon River in Whitehorse. Unfortunately, the 
only available waterfront land in the city was owned by the municipal government, which had purchased the former Motorways Trucking Yard property several years earlier. Previous city councils had been generally hostile to a Kwanlin Dün land claims agreement. However, the newly elected city council, led by Mayor Ernie Bourassa, was more receptive and was willing to dispose of the Motorways property as long as it was developed by the First Nation to foster tourism. Moreover, Bourassa and other city officials liked Kwanlin Dün's plan to build a commercial office, a retail building, a restaurant, a small hotel, and a cultural centre on the Motorways property. The city ultimately agreed to sell the Motorways property to the territorial government so that it could then include it in the Kwanlin Dün treaty (Armour, 2006; Bourassa, 2006; Stockdale, 2006; Tobin, 2002b; Waddell, 2003).

\section{A Final Agreement in Sight: 2002 to 2005}

Several days before the March 31, 2002, deadline, Kwanlin Dün negotiators signed a memorandum of understanding (MOU) with their government counterparts, thus settling all of the major issues that the team had originally identified in 1999 (Beaudoin, 2006; Brown, 2006; Tobin, 2002a). With a completed MOU in hand, the negotiators spent the next year and half finalizing and initialing the documents that would make up the Kwanlin Dün treaty. These documents included the final agreement, the self-government agreement, the implementation plans, and the ancillary agreements (specifically the Kwanlin Dün Programs and Services Transfer Agreements and Kwanlin Dün Collateral Agreement). The agreement was ratified in 2004 and came into operation in 2005 (Tobin, 2005).

The Kwanlin Dün Final Agreement is noteworthy on a number of fronts. First, although Kwanlin Dün received the smallest amount of settlement lands among the Yukon First Nations, its lands have the potential to be the most valuable in terms of economic development by virtue of being located in the territorial capital. Second, chapter 21 of the treaty on taxation of settlement lands is quite different from other Yukon agreements in that it allows Kwanlin Dün settlement lands to remain tax free until the lands are developed or if certain time periods (usually between 15 to 20 years) are reached (Flynn, 2006; Kwanlin Dün First Nation Final Agreement, 2004: 345). Third, the economic measures chapter gives the Kwanlin Dün government additional powers in light of the few fish and wildlife resources on its lands. These powers include a strategic economic development investment fund, the right to acquire up to a 25 per cent interest in resource and energy products, control over quarry leases, a plan to increase the number of Aboriginal government workers on Kwanlin Dün lands, the first right to acquire certain lands if the government 
decides to dispose of them, and the first right to acquire a number of gaming, tourism and farming licenses. Fourth, Kwanlin Dün agreed to provide a compatible land use guide in the treaty to give advance notice to non-Aboriginal peoples who owned lands next to Kwanlin Dün lands about the band's intentions regarding land use. Fifth, most of Kwanlin Dün's lands in the city of Whitehorse was designated as type 2, meaning that Kwanlin Dün has limited self-government powers over these parcels. The result is that in most cases they must adopt and use city bylaws and enforcement officers for these lands. Finally, the city and Kwanlin Dün negotiated a municipal services and infrastructure agreement, listing the types of municipal services that the city would provide in exchange for certain amounts of monetary compensation (Kwanlin Dün First Nation Final Agreement, 2004).

\section{Inter-"Municipal" Co-operation as the Basis for CLC Resolution: An Analysis of the Decision to Transfer Municipal Land}

According to federal, territorial, municipal, and Aboriginal officials, the inclusion of waterfront land was the deal breaker for the treaty. Yet, at the time there was no waterfront land available except for those owned by the city. In essence, the city's ownership of waterfront land gave it a powerful veto over negotiations. Why did the city of Whitehorse agree to sell the Motorways property to YTG so that it could include it in the treaty?

Before providing our answer to this question, it is important to emphasize that there were no official negotiations between Whitehorse and Kwanlin Dün representatives. According to a number of interviewees, Chief Rick O'Brien visited Mayor Ernie Bourassa in his office one day and mentioned that he was having difficulty with Yukon territorial government officials over the inclusion of waterfront land and suggested that this issue was developing into a major obstacle to the completion of the treaty. The mayor informed Chief O'Brien that the city owned the Motorways Trucking Yard parcel and did not care who developed it as long as it was developed. After that meeting, Mayor Bourassa approached Yukon Premier Duncan and some of her staff and ministers with the idea of selling the property to the territorial government, but, according to Mayor Bourassa (2006) and City Councillor Stockdale (2006), they rejected the offer. Two months later, after significant pressure from Chief O'Brien and his negotiating team, territorial officials approached the mayor about whether his offer was still available and he said yes, thus facilitating the completion of the treaty.

From a theoretical perspective a number of factors played a role in shaping this decision. The central factors to this case from among those 
developed in the theoretical framework are internal opportunities, autonomy considerations, existing relationships, and, most importantly, leadership. Indeed, local leadership was significant both in the decision to reopen negotiations and in the crucial sale of the waterfront lands.

Because negotiations never took place directly between the Kwanlin Dün and the city of Whitehorse questions of power asymmetry between leaders in this case were not a factor. However, several other institutional and milieu considerations did play a role in the decision to transfer the land to YTG. Concerns about the impact of the treaty on local autonomy certainly factored into the final decision to sell the land. Primary among these concerns were questions about how the land would be taxed and serviced. From the municipal point of view there was an opportunity cost associated with ceding urban territory in the form of lost assessment. This issue was a particular concern since the territorial government had the authority to alter taxation regulations as part of the land claims negotiations. Some uncertainty existed about how the municipality and First Nations governments would relate over issues of taxation, service delivery, and jurisdictional issues as many of these issues were being resolved concurrently with the transfer through the selfgovernment treaty negotiation process. Under the final agreement Kwanlin Dün First Nations occupying settlement lands within the city are subject to local bylaws to the degree that they are applicable. The Kwanlin Dün have the authority to set their own legislation, supersede local bylaws, and take on authority for local functions (such as planning and zoning) as a self-governing community; however, this is rarely done. It also establishes that settlement lands within the city boundaries are subject to municipal property taxes. However, prior to the transfer of lands the municipality had only a vague idea of the fiscal ramifications of the deal as it related to assessment, but because the sale was projected to be largely revenue-neutral in the long term, co-operation on this issue was more forthcoming.

Significantly, the availability of information about how the city and First Nations government would relate to one another in a shared municipal space was helpful to the decision to transfer lands. Prior to the agreement the city of Whitehorse had a history of co-operation with urban Kwanlin Dün-particularly on issues regarding the servicing of First Nations land. These service agreements were typically mundane and dealt with issues such as water and waste removal agreements. In fact, as the transferred lands were undeveloped at the time, the city and Kwanlin Dün governments entered into a joint agreement to service the parcel on a cost-sharing basis. This agreement was negotiated separately from the land transfer and claims agreement. However, the precedent of previous similar negotiations and relationships eliminated a good deal of the uncertainty surrounding the transfer and smoothed the process of the sale. 
From the perspective of internal and external threats, the most significant in this case related to internal opportunities that the transfer afforded. One local official commented that the development of the waterfront land and construction of a Kwanlin Dün cultural centre were not construed as bad outcomes from the city's point of view. Separate from fiscal considerations often associated with development are issues related to the public good and civic values. Kwanlin Dün and non-Aboriginal Whitehorse communities have co-existed for a very long time and will and must continue to occupy the same space. Maintaining a long-term functional relationship is seen as a priority and a matter of pride. As such the city of Whitehorse endorsed the development (still pending) of the cultural centre as a visible and accessible way of integrating the Kwanlin Dün culture into the city and as an opportunity to celebrate its diversity. If the development of the land had been contested, it is unclear whether the transfer would have been more difficult to negotiate. However, it is interesting to note that in this case, interests surrounding the purposing of the land generally aligned.

Senior government involvement can be a powerful catalyst for cooperation. Because municipal governments have no constitutional standing and are governed by their provincial and territorial governments, the potential existed for YTG to exert pressure on Whitehorse to expedite the sale. In theory, the threat of expropriation could have been used to compel a non-compliant council to an agreement. In this case, upper-level government involvement was not necessary, nor was any threat informally made. ${ }^{6}$ That the city of Whitehorse was generally compliant establishes that this is indeed a case of voluntary co-operation in which the city acted as an autonomous agent in the decision to transfer the land.

The most important factor was a change in Kwanlin Dün and city of Whitehorse leadership. In 2000, the city of Whitehorse elected a new mayor, Ernie Bourassa, and a more progressive city council. In contrast to previous councils, interviewees mentioned that Bourassa's government was more open to the idea of a completed treaty. Bourassa's government was interested in developing the waterfront and saw the treaty as an opportunity to facilitate the development of that property for the purposes of tourism. Indeed, the city officials felt that a treaty was necessary because the uncertainty regarding the nature and extent of Kwanlin Dün's land claim made it impossible to develop the waterfront properties. Interviewees also mentioned that there was pressure emanating from Whitehorse citizens who were tired of the negotiation process and wanted certainty regarding access rules to municipal lands and clear designations of which lands belonged to Kwanlin Dün.

City co-operation was also facilitated by the election of Kwanlin Dün Chief Rick O’Brien in 1998. In contrast to previous Kwanlin Dün governments, O'Brien quickly gained the respect of federal, territorial, 
and local officials for his ability to reduce political infighting, improve financial management, and show a commitment to negotiating a deal that would be compatible with federal, territorial, and especially municipal, interests (for the importance of compatible goals for treaty completion, see Alcantara, 2007; Abele and Prince, 2003). This latter point is important because it explains why Kwanlin Dün agreed to a number of provisions in the treaty that try to take into account municipal interests. For one, the Kwanlin Dün First Nation agreed to provide land use designations for those lands located within municipal boundaries that were compatible with adjacent non-treaty lands. Negotiators also agreed that most of Kwanlin Dün's lands would be subject to Kwanlin Dün laws that were reproductions of city bylaws and were enforced by city bylaw officers. For instance, Kwanlin Dün could pave undeveloped roads but only in accordance with city standards. Finally, Kwanlin Dün agreed to have the city provide municipal services like garbage collection and snow removal, among other things, in exchange for sufficient monetary compensation.

In essence, municipal co-operation was facilitated by a change in municipal and Aboriginal leadership and the confluence of institutional and milieu variables that generally supported a co-operative outcome. While other variables contributed to an amenable incentive structure for the land transfer, leaders on both sides of the deal played an instrumental role in smoothing the transition. It is remarkable that in the context of such complex and protracted land claims negotiations the city of Whitehorse was able and willing to play a critical role to facilitate an agreement through this secondary land transfer deal.

\section{Leaders Matter: An Explanation}

It is clear from the above historical narrative and analysis that significant institutional and milieu constraints were present. City of Whitehorse officials were interested in economic development opportunities and were concerned about the effect that land claims agreements would have on their ability to develop the waterfront and other Aboriginal-claimed lands within city borders (Stockdale 2006; Bourassa 2006). Developing the waterfront, in particular, had long been a goal for city officials throughout the 1990s and until today. Hampering the realization of these goals were factors such as not having a direct voice in land claims negotiations and therefore not having any direct influence on how the land claims agreement would affect municipal interests in development and land use. There was also some significant fear regarding the effect of a completed land claims agreement on the jurisdiction of the municipal government. Indeed, city officials and politicians were concerned that the treaty would result in a 
checkerboard of Kwanlin Dün First Nation (KDFN) and city of Whitehorse laws and regulations. One city official and several territorial officials also mentioned that the relationship between some municipal and KDFN officials was strained prior to 2000 .

In terms of KDFN leaders, their goal was to somehow acquire waterfront land. Since all of the land surrounding the river was privately owned except for the city-owned Motorways Trucking Yard, and since there was no possibility of expropriation due to internal federal and territorial policies (Flynn 2006; Koepke 2006), it was clear that KDFN officials would have to somehow convince the city of Whitehorse to dispose of its trucking yard property. Yet the ability of KDFN officials to do so was very much hampered by internal conflicts and the state of their leadership, described above. KDFN local politics prior to the election of Chief O'Brien was very much in a state of paralysis due to infighting between two factions who were struggling over the leadership of the band.

Although these institutional and milieu constraints were significant, they were eventually overcome by the emergence of new leaders in both communities, armed with significant civic capital resources. In the case of Chief Rick O'Brien, his resources came partly from victory over the factional candidates that had dominated KDFN politics previously. During his campaign, he stressed constantly that he was not connected with either faction. Instead, he was strongly committed to band unity and responsible and accountable government. He also promised to restart and complete land claims negotiations, which had been derailed by infighting among local factional leaders. Overall, his electoral victory reflected a community that now wanted to move beyond the infighting to restore a more functional government. It also reflected a desire to restart and complete treaty negotiations. Indeed, federal, territorial, and KDFN officials all point to O'Brien's election as a crucial turning point in KDFN negotiations.

Mayor Ernie Bourassa's electoral victory in 2000 was very much a surprise. He was a political novice, having never held public office, and had a much lower profile than the other candidates, such as Tom O'Hara. At the same time, the city government was experiencing significant turnover among its senior officials, coinciding with the retirement of the incumbent mayor, Kathy Watson. Bourassa's successful campaign focused on waterfront development and to a lesser extent, the completion of land claims negotiations, both of which were welcomed by the Whitehorse electorate. As such, Bourassa's victory meant that he had a clear mandate to move on waterfront development and on the land claims issue. Once elected, he fulfilled this mandate by transferring the Motorways property to the territorial government with the knowledge that KDFN planned to develop it in a way that was congruent with the city's vision of the waterfront, described above. 
As well, the land transfer was facilitated by a set of pre-existing personal relationships that Ernie Bourassa had with KDFN members and leaders. The two most important of these relationships were with Chief Rick O'Brien and with KDFN negotiator Mike Smith, who later succeeded O'Brien as chief of KDFN in 2003. Bourassa was friends with both prior to becoming the Mayor of Whitehorse, first meeting Mike Smith, for instance, while playing minor hockey. These pre-existing relationships were crucial in the decision of Bourassa to transfer the Motorways Trucking Yard to the YTG for inclusion in the KDFN deal. Once the transfer was completed, KDFN officials agreed to adopt a set of unique treaty provisions, described above, that were compatible with the political and economic interests of the municipality.

\section{Conclusion}

Although this paper examines only one case, future research could profitably draw upon our framework and findings to understand and explain other treaty negotiations involving municipal lands. As well, our framework could be applied usefully to other instances of First Nation-municipal co-operation that do not involve CLC negotiations. The Aboriginal politics and municipal governance literatures have largely ignored the wide range of non-treaty intergovernmental relations that have formed between First Nation and municipal governments. For instance, First Nation and municipal governments are currently co-operating with respect to economic development initiatives, land use planning, and the provision of municipal services, among other things. Our framework would be helpful for understanding these and other cases of co-operation between different types of Aboriginal and municipal governments throughout the country and perhaps elsewhere in other settler societies like the United States, Australia, and New Zealand. Indeed, even in these countries, very little is known about how or why Indigenous and municipal governments co-ordinate their activities.

\section{Notes}

1 It should be noted here that treaty negotiations involved formal bargaining between the federal government, the territorial government, and the Kwanlin Dün First Nation.

2 Cities have, indeed, partnered with federal authorities on specific policies - in these cases the provincial governments are also typically involved. On some issues cities have been able to negotiate directly with the federal government, bypassing provincial stewardship; however instances of this are rare and do not indicate the emergence of municipal-federal bilateral relations comparable to that of First Nations councils in Canada. 
3 "Adapted" to the degree that the following framework is applied with some variations to account for significant differences. When this is a factor it is noted in the theoretical framework.

4 It should be noted that, on the above three indicators, many of these institutional factors are likely to be similar across cases in Canada. From a qualitative point of view, it is still worth exploring the impact these variables have on decision making and how they contribute to the story of municipal-First Nations co-operation. However, they will be of most use in international comparisons where there will likely be more variation between cases on these institutional dimensions.

5 The Northern Native Broadcasting, Yukon (NNBY) provides radio (CHON-FM 98.1) and television (NEDAA) programming on issues affecting Indians living in the Yukon. The NNBY is owned and operated by the fourteen Yukon First Nations.

6 Not only were threats unnecessary, but one local official commented that it was doubtful that expropriation could legally take place as it would be difficult to make the case that it was in the public good, the acid test for expropriation cases.

\section{References}

Abele, Frances and Michael Prince. 2003. "Aboriginal Governance and Canadian Federalism: A To-Do List for Canada." In New Trends in Canadian Federalism, ed. François Rocher and Miriam Smith. Peterborough: Broadview Press.

Alcantara, Christopher. 2007. "Explaining Aboriginal Treaty Negotiation Outcomes in Canada: The Cases of the Inuit and the Innu in Labrador." Canadian Journal of Political Science 40 (1): 185-207.

Alcantara, Christopher. 2008. "To Treaty or Not to Treaty: Aboriginal Peoples and Comprehensive Land Claims Negotiations in Canada.” Publius: Journal of Federalism 38 (2): 343-69.

Armour, Karyn (assistant deputy minister for YT Land Claims Secretariat). 2006. Interview. Whitehorse YT, October 24.

Beaudoin, Tom (land claims director, Kwanlin Dun First Nation). 2006. Interview. Whitehorse YT. October 26.

Bourassa, Ernie (former mayor of the City of Whitehorse, 2000-2006). 2006. Interview. Whitehorse YT, October 23.

Brass, Daniel and David Krackhardt. 1999. "Social Capital for Twenty-first Century Leaders." In Out-of-the-Box Leadership Challenges for the $21^{\text {st }}$ Century Army, ed. J.G. Hunt and R.L. Phillips. Burlington: Elsevier.

Brown, Keith (former legal counsel for Kwanlin Dün and Kaska First Nations). 2006. Interview. Vancouver BC, October 20.

De Costa, Ravi. 2003. "Treaties in British Columbia: The Search for a New Relationship." International Journal of Canadian Studies 27: 173-96.

Department of Indian Affairs and Northern Development (DIAND) 2002. A Strong Future for All: Settling Yukon Land Claims. Ottawa: Minister of Indian Affairs and Northern Development Canada.

Diamond, Billy. 1985. "Aboriginal Rights: The James Bay Experience." In The Quest for Justice: Aboriginal Peoples and Aboriginal Rights, ed. M. Boldt, J.A. Long and L.L. Bear. Toronto: University of Toronto Press.

Dust, Theresa. 1997. "The Impact of Aboriginal Land Claims and Self-Government on Canadian Municipalities.” Canadian Public Administration 40 (3): 481-94.

Feiock, Richard C. 2004. "Introduction: Regionalism and Institutional Collective Action." In Metropolitan Governance: Conflict, Competition and Co-operation, ed. Richard C. Feiock. Washington DC: Georgetown University Press. 
Feiock, Richard C. 2007. "Rational Choice and Regional Governance." Journal of Urban Affairs 29 (1): 47-63.

Feit, Harvey A. 1980. "Negotiating Recognition of Aboriginal Rights: History, Strategies and Reactions to the James Bay and Northern Quebec Agreement." Canadian Journal of Anthropology 1 (2): 159-72.

Flynn, Dermot (chief YT negotiator for the Kaska and Kwanlin Dün files, from 1983present). 2006. Interview. Whitehorse YT, October 24.

Frideres, James S. 1986. "Chapter 11: Native Claims and Settlement in Yukon.” In Arduous Journey: Canadian Indians and Decolonization, ed. Rick Ponting. Toronto: McClelland and Stewart.

Joe, Dave (former legal counsel for Council of Yukon Indians, negotiator on the umbrella final agreement). 2006. Interview. Vancouver BC, October 16.

King, Anne (legal counsel for the federal government, Kwanlin Dün final agreement negotiations, 1991-2004). 2006. Interview. Whitehorse YT. October 26.

Koepke, Tim (federal chief negotiator for the UFA, and the Kaska and Kwanlin Dün files). 2006. Interview. Vancouver BC, October 18.

Kwanlin Dün First Nation Final Agreement. 2004. Ottawa: Minister of Indian Affairs and Northern Development.

Lowndes, Vivien and David Wilson. 2001. "Social Capital and Local Governance: Exploring the Institutional Design Variable." Political Studies 49: 629-47.

McAllister, Mary Louise. 2004. Governing Ourselves? The Politics of Canadian Communities. Vancouver: UBC Press.

McArthur, Doug (former deputy minister YT Land Claims Secretariat 1989-1992). 2006. Interview. Vancouver BC, October 20.

McClellan, Catherine. 1987. Part of the Land, Part of the Water: A History of the Yukon Indians. Vancouver: Douglas \& McIntyre.

McCullough, Lesley (director of research for YT Land Claims Secretariat). 2006. Interview. Whitehorse, YT, October 24.

McNeely, Sean. 1998. "Meeting Was Extremely Productive." Whitehorse Daily Star [October 6 and page of original article]. http://www.whitehorsestar.com (January $18,2007)$.

Mitander, Victor (former council of Yukon Indians negotiator on the umbrella final agreement). 2006. Interview. Whitehorse YT, October 23.

Nelles, Jen. 2009. "Civic Capital and the Dynamics of Intermunicipal Co-operation for Regional Economic Development." Doctoral dissertation. University of Toronto, Toronto, Ontario.

Nelles, Jen and David Wolfe. 2008. "Civic Capital in the Waterloo Region: Enabling Regional Economic Governance." Working Paper. Ontario Network on the Regional Innovation System. Toronto: Munk Centre for International Studies, University of Toronto.

Northern Native Broadcasting Yukon. 1996. NEDAA Video. Season 10, Show \#9.

Northern Native Broadcasting Yukon. 1998. "Kwanlin Dün History” NEDAA Video. Season 12 , Show \#16.

Oakerson, R. J. 2004. “The Study of Metropolitan Governance.” In R. Feiock (Ed.), Metropolitan Governance: Conflict, Competition and Cooperation (pp. 17-45). Washington, DC: Georgetown University Press.

Ostrom, Elinor. 2005. Understanding Institutional Diversity. Princeton NJ: Princeton University Press.

Parker, Bridgette. 1999. "Business as Usual.” Whitehorse Daily Star [January 27 and page of original article]. http://www.whitehorsestar.com (January 18, 2007).

Penikett, Tony. 2006. Reconciliation: First Nations Treaty Making in British Columbia. Vancouver: Douglas \& McIntyre. 
Post, S. 2004. "Metropolitan Governance and Institutional Collective Action". In R. Feiock (Ed.), Metropolitan Governance: Conflict, Competition and Cooperation (pp. 6794). Washington, DC: Georgetown University Press.

Rynard, Paul. 2001. "Ally or Colonizer? The Federal State, the Cree Nation, and the James Bay Agreement." Journal of Canadian Studies 36 (2): 8-47.

Samson, Colin. 1999. "The Dispossession of the Innu and the Colonial Magic of Canadian Liberalism." Citizenship Studies 3 (1): 5-25.

Scholtz, Christa. 2006. Negotiating Claims: The Emergence of Indigenous Land Claim Negotiation Policies in Australia, Canada, New Zealand, and the United States. New York: Routledge.

Steinacker, A. 2004. "Game-Theoretic Models of Metropolitan Cooperation". In R. Feicok (Ed.), Metropolitan Governance: Conflict, Competition and Cooperation (pp. 4666). Washington, DC: Georgetown University Press.

Stockdale, Dave (Whitehorse city councillor 1983-present). 2006. Interview. Whitehorse YT, October 23.

Tennant, Paul. 2000. "Delgamuukuw and Diplomacy: First Nations and Municipalities in British Columbia." In Beyond the Nass Valley: National Implications of the Supreme Court's Delgamuukw Decision, ed. O. Lippert. Toronto: The Fraser Institute.

Tobin, Chuck. 2000. "Land claims program extended." Whitehorse Daily Star [January 14 and page of original article]. http://www.whitehorsestar.com (January 18, 2007).

Tobin, Chuck. 2002a. "Eleventh-hour claim deals signed." Whitehorse Daily Star [April 1 and page of original article]. http://www.whitehorsestar.com (January 18, 2007).

Tobin, Chuck. 2002b. "Document summarizes terms of Kwanlin Dün land claim." Whitehorse Daily Star [December 11 and page of original article]. http://www.whitehorsestar. com (January 18, 2007).

Tobin, Chuck. 2005. "It is the beginning of a new future." Whitehorse Daily Star [February 21 and page of original article]. http://www.whitehorsestar.com (January 18, 2007).

Tully, James. 2001. "Reconsidering the BC Treaty Process." In Speaking Truth to Power: A Treaty Forum. Ottawa: Law Commission of Canada.

Waddell, Stephanie. 2003. "City is closer to selling waterfront area to YTG." Whitehorse Daily Star [June 18 and page of original article]. http://www.whitehorsestar.com (January 18,2007$)$.

Woolford, Andrew. 2005. Between Justice and Certainty: Treaty-Making in Modern-Day British Columbia. Vancouver: UBC Press. 